\title{
PERBAIKAN PENGELOLAAN UMKM GUNA PENGEMBANGAN USAHA MIKRO
}

\author{
SCIENCE AND TECHNOLOGY FOR SOCIETY \\ MANAGEMENT IMPROVEMENT FOR DEVELOPMENT SME'S \\ ${ }^{1)}$ Rosita, ${ }^{2)}$ Ida Ayu Kade Rachmawati Kusasih, ${ }^{3)}$ Budi Istiyanto \\ ${ }^{1)}$ Program Studi Akuntansi, ${ }^{2,3)}$ Program Studi Manajemen \\ STIE Surakarta \\ Email : ${ }^{1)}$ rositasetiawan@yahoo.co.id
}

\begin{abstract}
ABSTRAK
Program pengabdian ini dilakukan pada UMKM yang bergerak daam bidang usaha manufaktur (mitra 1) yaitu Nufarozan Bedding Goods dan UMKM bergerak dalam bidang dagang (mitra 2) yaitu SB Alat Kebersihan. Mitra 1 yang memiliki permsaalahan manajemen usaha yang belum profesional dan belum menghasilkan pendapatan usaha yang optimal sehingga kesulitan untuk bisa mengembangkan usahanya. Demikian pula dengan mitra 2 memiliki permasalahan yang hampir sama yaitu pengelolaan yang masih menjadi satu dengan pengelolaan rumah tangga sehingga belum bisa optimal dalam usahanya. Penataan dan sarana untuk memperoleh pendapatan dari penjualan kurang diperhatikan, sehingga pendapatan usaha hanya cukup untuk bertahan hidup saja. Pelaksanaan kegiatan pengabdian dilakukan di kedua UMKM mitra dengan memberikan pendampingan manajemen dan pengelolaan keuangan. Kegiatan pendampingan dimulai dari perbaikan pengelolaan keuangan dari kedua mitra. Penghitungan biaya produksi diberikan konsep untuk mitra Nufarozan, demikian juga dengan pengelolaan kas usaha melalui pencatatan arus kas. Kemudian ada perbaikan ruang usaha berupa layout usaha yang lebih efektif dan efisien. Pada mitra SB Alat Kebersihan juga dilakukan perbaikan pendampingan pengelolaan keuangan dari pengelolaan persediaan barang dagangan dan pencatatan arus kas. Untuk pengelolaan manajemen ada perbaikan layout ruang display barang dagangan. Kegiatan pengabdian dengan telah menghasilkan manajemen produksi dan manajemen usaha secara keseluruhan yang lebih baik bagi mitra 1 dan mitra 2. Ruang usaha telah terbentuk untuk mitra 1 dan mitra 2. Pemasaran online juga telah dilakukan melalui blog yang telah dibuatkan oleh tim pelaksana.
\end{abstract}

Kata kunci : UMKM, manajemen profesional, pemasaran, keuangan, pendapatan, layout, pemasaran online, ruang usaha

\begin{abstract}
This study proposed to SMEs and it will be conducted on Nufarozan Bedding Goods as the first partnership of manufacture business and SB Alat Kebersihan as the second partnership of trading company. The first partner has not develop yet in professional management and not to generate revenue optimized yet. Like the first partner, the second partner has the similar problems in managing and developing system. In short, the lack of attention in managing and structuring is fundamental problem in the business and it is not growing satisfy. The study will be conducted by providing assistance and financial management to the partnership. The activities will be started from the financial management; which is the measurement of cost production, cash flow and cash management will be provided for Mufarozan (fist partner); moreover, it will be given several improvement in the layout of business more effective and efficient. Furthermore, for SB Alat Kebersihan will be assisting on the financial management of inventory and cash flows; indeed, for managing also given by providing space layout for inventory display.According to the results that overall, the production of management and business activities are better both of partnership.The business area has been formed and also online marketing has been carried out through a website or
\end{abstract}


blog. Furthermore, hopefully both of partnership have to enhance the business activities; moreover, the partnership will be guidedcontinuously as responsibility of program.

Keyword: SMEs, professional management, marketing, finance, revenue, layout, online marketing, business space

Submited: 10 Agustus 2016 Revision :27 Agustus 2016 Accepted : 31 Agustus 2016

\section{PENDAHULUAN}

UMKM di Indonesia baru menjadi magnet utama pada perekonomian saat ini. Seperti diketahui bahwa UMKM di Indonesia memiliki jumlah yang jauh lebih banyak dibandingkan dengan perusahaan yang berskala besar. Tidak seperti negaranegara yang memiliki industry maju yang perekonomiannya digerakkan oleh perusahaan yang berskala besar, namun di Indonesia malah sebaliknya. Maka sangat penting dan menjadi prioritas utama bahwa pemerintah Indonesia harus dapat membuat sector UMKM menjadi bergairah untuk dapat berkompetisi dengan UMKM dari negara lain yang sudah mulai memasuki era MEA. Hal ini juga dialami oleh UMKM yang menjadi mitra dari pengabdian yang dilakukan team pengabdi. Latar belakang dan permasalahan pada mitra diuraikan dalam bagian pendahuluan ini.

\section{Mitra 1 (UMKM NUFAROZAN Bedding Goods)}

UMKM NUFAROZAN BEDDING GOOD adalah usaha keluarga yang bergerak dibidang produksi dan penjualan perlengkapan rumah tangga khususnya perlengkapan bedroom. UMKM ini berdiri pada awal pada 3 Maret 2013. Produk yang telah dihasilkan oleh UMKM ini adalah berupa produk sprei, bedcover, bantal, guling dakron, dan cushion sofa. Selain menghasilkan produk tersebut UMKM ini juga melakukan penjualan kasur busa.

Pada awal tahun 2014 UKM ini mulai melakukan penjualan ke Rumah Sakit dalam penyediaan kasur pasien. Hal ini berkembang ke pakaian kerja dari beberapa rumah sakit. Dibawah ini beberapa informasi yang tentang UMKM Nufarozan Bedding Goods

a. Lokasi dan Kondisi

1) Nufarozan Bedding Goods berlokasi di perum Bumi Singkil Permai Blok K7 RT 2 RW 10.

2) Dalam produksinya mempekerjakan tenaga kerja borongan berjumlah 3 orang

3) Peralatan yang digunakan masih minim; 2 mesin jahit dan 1 mesin obras

4) Pembukuan sekedar tercatat.

5) Pemasaran belum dikelola secara optimal.

6) Modal sangat terbatas untuk memenuhi permintaan konsumen ataupun pesanan

b. Manajemen dan Keorganisasian

1) Pengelolaan, manajemen keluarga

2) Perusahaan belum berbadan hukum

3) Yang telah berjalan NPWP atas nama perseorangan Eko Atmadi.

c. Catatan dan Informasi Lainnya

1) Telah dapat menjual barang hasil produksi kepada rumah sakit daerah di Boyolali.

2) Pendapatan kotor dari penjualan produk tahun 2014 sebesar Rp.23.150.000,(dua puluh tiga juta seratus lima puluh ribu rupiah).

3) Memiliki satu agen toko dengan ratarata pendapatan Rp. 1.800.000,--

4) Penjualan produk melalui direct selling dan sales freelance.

\section{Mitra 2 (UMKM “SB" ALAT KEBERSIHAN)}

Di Kota Klaten ada beberapa usaha dagang berupa dagang peralatan 
kebersihan. Meskipun peralatan ini sederhana dan masih terbuat dari bahan tradisional namun masih banyak diminati oleh masyarakat. Usaha dagang seperti ini akan membawa dampak positif bagi pengarajin alat-alat kebersihan tradisional yang harus bersaing dengan peralatan kebersihan yang diproduksi oleh pabrik perusahaan-perusahaan besar yang biasanya terbuat dari plastik. Hal ini yang memotivasi UMKM "SB" yang merupakan usaha dagang yang menyediakan peralatan kebersihan rumah tangga yang sebagian besar merupakan hasil produksi dari pengrajin-pengrajin alat kebersihan tradisional. UMKM seperti "SB" ini merupakan mata rantai yang penting dalam mempertahankan perekonomian yang sifatnya masih tradisional dalam menghadapi persaingan ekonomi yang semakin ketat saat ini

UMKM ini telah berdiri kurang lebih 1 tahun yaitu didirikan tanggal 13 Februari 2014. Dengan mengeluarkan modal pembelian barang dagangan dan tempat display kurang lebih Rp.10.000.000,-. Namun meskipun demikian pengelolaan usaha dagang ini masih sangat sederhana. Pembelian barang dagangan diambil dari pengrajin-pengrajin tradisional dari sekitar Klaten, Boyolali dan Muntilan. Penjualan yang terjadi selama ini masih sangat minim. UMKM ini dikelola sendiri oleh pemilik dengan dibantu seorang pegawai untuk melayani pembeli. Gaji yang diberikan kepada pegawai tersebut dibayarkan secara harian dengan upah Rp. 15.000,- per hari dan diberikan uang makan Rp. 5.000,- per hari. Biaya operasional setiap bulan seperti jumlah yang dijelaskan di atas, maka sangat berat UKMK ini untuk bisa bertahan dengan kondisi saat ini. Meskipun secara hitungan di atas kertas UMKM sudah memiliki laba setahun rata-rata $30 \%$ sampai dengan $40 \%$. Namun secara hitungan ekonomi masih menderita kerugian jika laba kotor masih harus dikurangi biaya operasional setiap bulannya.
Namun karena pemilik UMKM kurang memahami pengelolaan usaha yang baik maka hal tersebut tidak begitu dihiraukan selama masih ada aliran kas masuk setiap harinya.

$\begin{array}{llll}\text { UMKM } & \text { Mitra } & 1 & \text { (UMKM } \\ \text { NUFAROZAN } & \text { Bedding } & \text { Goods) } & \text { adalah } \\ \text { sebagai berikut : } & & & \end{array}$

1. Bagaimana cara manajemen produksi yang lebih profesional agar produk yang dihasilkan bisa optimal dengan keterbatasan alat produksi

2. Belum luasnya pangsa pasar hasil produksi sehingga mempengaruhi pendapatan (omset) dari UMKM ini.

3. Pengelolaan keuangan perusahaan yang jadi satu dengan rumah tangga sehingga berakibat pada ketidak lancaran arus kas dari UMKM ini.

Masalah Mitra 2 (UMKM "SB" ALAT KEBERSIHAN) adalah sebagai berikut :

1. Bagaimana cara manajemen persediaan yang lebih profesional agar barang dagangan bisa menghasikan pendapatan yang lebih optimal.

2. Pengelolaan keuangan perusahaan yang jadi satu dengan rumah tangga sehingga berakibat pada ketidak lancaran arus kas dari UMKM ini.

3. Layout tempat usaha dan belum luasnya pangsa pasar barang dagangan sehingga mempengaruhi pendapatan (omset) dari UMKM ini.

\section{METODE}

\section{Mitra 1 (UMKM NUFAROZAN Bedding Goods)}

Metode pelaksanaan program kegiatan pada UMKM manufaktur yang menjadi mitra adalah sebagai berikut :

a. Pengelolaan Bisnis Profesional UMKM Manufaktur

Metode pelaksanaan dalam program kegiatan untuk pengelolaan bisnis profesional yaitu dengan melakukan pembelajaran manajemen dan keuangan 
profesional dengan melakukannnya langsung praktek (Learning by Doing) pada bagian-bagian dalam operasional UMKM.

Kegiatannya adalah sebagai berikut :

1) Perbaikan pengelolaan manajemen dengan penyampaian materi manajemen dengan langsung beraktivitas di lapangan sesuai dengan kompetensi masing-masing anggota tim pelaksana pada setiap bagian operasional UMKM mitra.

2) Perbaikan pengelolaan keuangan dengan penyampaian materi laporan keuangan langsung di lapangan sesuai dengan kompetensi masing-masing anggota tim pelaksana pada setiap bagian operasional UMKM mitra

\section{b. Peningkatan Pendapatan}

Metode pelaksanaan program kegiatan untuk peningkatan pendapatan melalui peningkatan penjualan dan efisiensi biaya produksi yaitu memberikan pembelajaran Online Marketing kepada bagian penjualan dengan metode Learning by Doing. Efisiensi biaya produksi dengan cara memberikan pembelajaran pembuatan hitungan-hitungan berupa laporan biaya produksi.

Kegiatannya adalah sebagai berikut :

1) Pemasaran secara Online melalui penyampaian materi pembuatan toko online dengan langsung beraktivitas di lapangan sesuai dengan kompetensi masing-masing anggota tim pelaksana pada setiap bagian operasional UMKM mitra.

2) Penghitungan biaya produksi melalui penyampaian materi pembuatan laporan biaya produksi secara program Excel langsung di lapangan sesuai dengan kompetensi masing-masing anggota tim pelaksana pada setiap bagian operasional UMKM mitra

\section{Mitra 2 (UMKM "SB" Alat}

a. Pengelolaan Bisnis Profesional UMKM Dagang

Metode pelaksanaan dalam program kegiatan untuk pengelolaan bisnis profesional yaitu dengan melakukan pembelajaran manajemen dan keuangan profesional dengan melakukannnya langsung praktek (Learning by Doing) pada bagian-bagian dalam operasional UMKM.

Kegiatan nya adalah sebagai berikut :

1) Perbaikan pengelolaan manajemen melalui penyampaian materi manajemen dengan langsung beraktivitas di lapangan sesuai dengan kompetensi masing-masing anggota tim pelaksana pada setiap bagian operasional UMKM mitra.

2) Perbaikan pengelolaan keuangan melalui penyampaian materi laporan keuangan secara langsung di lapangan sesuai dengan kompetensi masingmasing anggota tim pelaksana pada setiap bagian operasional UMKM mitra.

b. Peningkatan Pendapatan

Metode pelaksanaan program kegiatan untuk peningkatan pendapatan melalui peningkatan penjualan yaitu dengan memberikan pembelajaran cara penataan outlet tempat usaha yang bisa menarik pembeli kepada karyawan yang menangani penjualan barang dagangan UMKM ini dengan metode Learning by Doing.

Kegiatan nya adalah sebagai berikut :

1) Pemasaran secara optimal, melalui penyampaian materi pembuatan outlet tempat usaha yang marketable dengan langsung beraktivitas di lapangan sesuai dengan kompetensi masing-masing anggota tim pelaksana pada setiap bagian operasional UMKM mitra.

2) Pembuatan laporan arus kas dan keuangan sederhana melalui penyampaian materi pembuatan laporan keuangan sederhana melalui program excel langsung di lapangan sesuai dengan kompetensi masing-masing anggota tim pelaksana pada setiap 
bagian operasional UMKM mitra, agar mitra dapat memperoleh informasi keuangan untuk dapat melakukan pengambilan keputusan ekonomi berkaitan dengan usahanya.

\section{HASIL DAN PEMBAHASAN}

Hasil dari pengabdian ini sejalan dengan temuan penelitian sebelumnya yang dilakukan oleh Rosita, dkk (2014) pada kinerja UMKM di Surakarta yang menghasilkan bahwa system pelaporan manajemen dan laporan keuangan memiliki pengaruh signifikan terhadap kinerja UMKM. Penelitian Rosita dkk (2015) juga mengungkapkan bahwa ada pengaruh system informasi akuntansi terhadap laporan keuangan sesuai dengan SAK ETAP. Laporan keuangan yang dibuat koperasi di wilayah Kota Surakarta ditentukan pula oleh gaya pengelolaan manajemen yang dilakukan.

Pengabdian ini juga sejalan dengan penelitian sebelumnya yang dilakukan Rosita dkk (2015) yang menunjukkan bahwa pemanfaatan dan penerapan sistem informasi akuntansi dan sistem informasi pemasaran di UMKM masih tergolong sederhana, yang perlu diperhatikan adalah agar sistem bisa sesuai dengan kebutuhan dan kapasitas para pengusaha mebel di industri mebel Mojosongo.

Berdasarkan penelitian yang pernah ada berkaitan dengan UMKM dan pengelolaannya sehingga dilakukan program pengabdian yang berkaitan dengan hasil penelitian tentang pengelolaan (manajemen) profesional baik dari sisi keuangan maupun pemasarannya.

Pengabdian dilakukan pada 2 mitra dengan kondisi yang terjadi pada saat pengabdian dilakukan dapat dirinci dan dijelaskan sebagai berikut :

\section{Mitra 1 (UMKM NUFAROZAN Bedding Goods)}

Mitra ini dahulu pada saat pengajuan proposal untuk pengabdian telah banyak melakukan produksi dan penjualan kepada instansi pemerintah misal RSUD kabupaten setempat, namun pada saat pengabdi memulai kegiatan berupa observasi ternyata UMKM mitra baru mengalami masalah dan sementara berhenti untuk berproduksi karena terkendala oleh pelaporan pajak yang harus dilaporkan kepada kantor pajak. Sehingga ada sedikit pergeseran dari pelaksanaan kegiatan pengabdian. Namun program kegiatan mitra tetap seperti yang telah dirancang. Mitra juga memiliki kegiatan bisnis lainnya yaitu Biro Perjalanan Umroh. Sehingga dengan beberapa kegiatan bisnis yang dilakukan mitra menginginkan pendirian badan usaha. Badan usaha yang diusulkan oleh pengabdi adalah berbentuk CV (persekutuan) namun mitra menginginkan PT (Perseoran Terbatas). Dari berbagai masalah yang dihadapi di lapangan maka kegiatan yang dilakukan adalah sebagai berikut :

a. Perbaikan pengelolaan manajemen yang dilakukan dengan :

1) Pembuatan ruang usaha produksi atau show room produk jadi yang dipisahkan dengan ruang rumah tangga. Dalam hal ini mitra bersedia berkontribusi dengan mengeluarkan dana dalam pembuatan ruang usaha. Sehingga dana dari pengabdi hanya sebatas subsidi. Hal ini dibutuhkan oleh mitra karena mitra menggunakan ruang yang baru dibangun tersebut untuk ruang yang digunakan common use baik untuk ruangan display dari kegiatan usaha produksi bedding good maupun untuk ruang administrasi jasa tour umroh. Tim pelaksana tidak hanya mengarahkan ke ruang display hasil produksi maupun ruang produksi namun mitra yang menginginkan ruang itu untuk 2 kegiatan bisnis. Hal tersebut dapat dilaksanakan tanpa mengurangi kegiatan pokok dari program pengabdian yang dilakukan oleh tim.

2) Mitra ingin mendirikan PT dimana perijinannya minta dibantu oleh team pengabdi. Untuk pendirian PT tim pelaksana memberikan petunjuk arah 
pembuatan PT karena mitra juga masih memikirkan modal dasar dan modal disetor yang harus dilakukan oleh mitra. Di sini tim pelaksana menunjukkan cara-cara dan aturan-aturan yang harus dilakukan oleh mitra seandainya mitra benar-benar ingin membuat PT untuk badan hokum yang menaungi usaha UMKM nya. Namun sampai dengan laporan ini dibuat mitra masih berfikirfikir dan menunda pembuatan PT yang dimaksud.

3) Dalam perluasan pangsa pasar maka ada perbaikan media pemasaran secara online. Media online yang telah dibuatkan akan ditambah dengan menu bisnis lain yang sekarang sudah mulai dilakukan oleh mitra. Jadi dalam 1 media online berupa blog yang dinamakan sama dengan nama usahanya maka ditambah (dimanfaatkan) sekalian dengan memasarkan untuk usaha umrohnya. Alamat yang ada digunakan adalah

www.nufarozanpondokbisnis@blogs pot.com

b. Perbaikan pengelolaan keuangan yang dilakukan dengan :

1) Inventarisasi investasi pada usaha UMKM. Inventarisasi dari investasi yang dilakukan oleh mitra adalah langkah awal untuk dapat membuat laporan keuangan yang baik dan dapat mencerminkan kegiatan opersaional bisnis UMKM yang selama ini dilakukan agar lebih professional.

1. Konsultasi masalah perpajakan yang sedang dihadapi oleh pelaku UMKM

Mitra sedang menghadapi masalah pajak. Namun dalam hal ini pengabdi dapat mengusulkan penyelesaian melalui konsultan pajak yang memiliki kompetensi di bidang itu. Bukan masalah pengabdi tidak sanggup melaksanakan penyelesaian pajak yang sedang dihadapi namun pengabdi memiliki keterbatasan team yang tidak memiliki kompetensi di bidang itu.
2. Penghitungan biaya produksi yang tepat pada produk mitra

Penghitungan biaya produksi untuk produk-produk bedding good. Barangbarang produksi yang dibuat adalah sprei, sarung bantal dan guling.

3. Pembuatan laporan laba rugi

Laporan laba rugi dibuat format sesuai dengan yang berlaku umum untuk pengelolaan pencatatan keuangan sederhana UMKM. Laporan laba rugi dibuat secara excel. Laporan laba rugi diperoleh dari pencatatan transaksi keuangan yang terjadi di mitra mulai dari produksi sampai dengan penjualan dilakukan dengan mencatatnya dalam jurnal maupun buku besar yang sudah disetting dalam computer mitra yang digunakan untuk pengelolaan administrasi usaha.

4. Pembuatan laporan keuangan sederhana

Laporan ini juga sudah ada di computer mitra yang sudah di setting untuk pelaporan keuangan sederhana.

5. Pembuatan laporan arus kas

Pembuatan laporan arus kas juga sudah ada di dalam versi excel.

6. Pembuatan kartu produksi sederhana agar dapat mengontrol barang pada proses produksi.

Kartu produksi sudah dibuat khusus untuk produksi yang dilakukan oleh mitra agar mitra dapat mengikuti alur barang dari dibuat dari bahan baku sampai dengan produk jadi. Blog dengan alamat www.nufarozanpondokbisnis@blogspo t.com. telah mulai digunakan dengan setting penjualan alat kebersihan yang lebih luas area pemasarannya. 
7. Pembuatan penganggaran untuk produksi dan penjualan

Kegiatan ini yaitu membuat anggaran untuk produski dan penjualan agar mitra memiliki rencana untuk proses produksi yang dikaitkan dengan besarnya penjualan agar kegiatan usaha mitra lebih terarah dan dapat membandingkan dengan realisasinya sebagai bentuk pengontrolan dalam kegiatan usaha.

Semua yang dilakukan pada UMKM mitra bersifat pendampingan dengan melakukan perbaikan-perbaikan yang menjadi masalah pada mitra. Kegiatan pendampingan masih sebatas pada pemilik. Kegiatan pendampingan akan tetap dilakukan meskipun program kegiatan pengabdian hanya sampai setahun. Hal ini dilakukan karena sudah menjadi komitmen antara pengabdi dengan mitra agar UMKM dapat berjalan dengan lebih baik lagi. Evaluasi dan pengawasan berkaitan dengan program kegiatan juga akan tetap dilakukan oleh pengabdi.

\section{a. Mitra 2 (UMKM "SB" Alat Kebersihan)}

Kegiatan pengabdian dilakukan pada mitra ini dengan beberapa program kegiatan seperti yang telah direncanakan. Kegiatan tersebut adalah sebagai berikut :

\section{a) Perbaikan pengelolaan manajemen}

1. Perbaikan layout dalam ruang usaha dan penyediaan variasi barang dagangan.

Dengan perbaikan ini ada hal yang dapat menambah nilai pada mitra yaitu sebelum adanya kegiatan pengabdian usaha mitra memiliki layout yang tidak yang kurang marketable dan terlalu menggunakan tempat yang terlalu luas dimana sebenarnya tempat tersebut dapat diminimalkan agar efisien dan efektif. Setelah program kegiatan pengabdian ini dilakukan maka tatanan layout di mitra lebih baik dan menghemat tempat. Sebelumnya mitra menggunakan dua ruang usaha, yang sebenarnya dengan penataan ruang yang baik dapat hanya menggunakan satu ruangan. Sehingga ada satu ruang yang dapat diguankan untuk kegiatan lain yang dapat dilakukan oleh mitra agar dapat menciptakan diversifikasi bisnis selain yang sudah ada sekarang ini.

2. Pembuatan pemasaran secara online agar dapat memperluas pangsa pasar penjualan barang dagangan.

Pembuatan blogspot untuk jualan online telah dilakukan oleh pengabdi. Hal ini dimaksudkan untuk memperluas area pemasarannya. Alamat blog yang digunakan untuk mitra adalah www.klatenhousehold@blogspot.com

b) Perbaikan pengelolaan keuangan

1. Pembuatan laporan keuangan sederhana

Pembuatan laporan keuangan sederhana dimulai dari neraca, laporan laba rugi sampai dengan laporan arus kas yang telah di setting ke computer milik mitra. Pegawai dari mitra yang melakukan pembukuan karena sesuai dengan kompetensinya yaitu lulusan dari SMK jurusan akuntansi. Hal ini mempermudah pengabdi dalam mentransfer knowledge tentang pembukuan (pelaporan) keuangan sederhana. Laporan sementara yang dibuat adalah laporan keuangan yaitu laporan penjualan dan laba rugi serta arus kas dari mitra. Pendampingan dengan melakukan evaluasi dan pengantrolan dari program kegiatan terus dilakukan sebgai komitmen dari pengabdi kepada mitra.

2. Pembuatan kartu stok

Kartu stok persediaan barang dagangan dibuat untuk membantu mitra mengendalikan persediaan barang dagangannya yang selama ini tidak pernah dibuat. Hal ini bertujuan untuk mengendalikan dan melakukan 
pengawasan terhadap barang dagangan yang dimiliki mitra dalam usaha ini.

Kegiatan dilakukan dengan cara pendampingan dengan melakukan perbaikan-perbaikan terhadap manajemen dan pengelolaan keuangan pada pemilik UMKM.

\section{SIMPULAN}

1. Pelaksanaan kegiatan pengabdian telah melakukan pendampingan perbaikan manajemen dan pengelolaan keuangan yang baik

2. Pembuatan layout ruang usaha juga dilakukan kepada kedua UMKM mitra 1 dan mitra 2. Ruang usaha di mitra 1 dapat digunakan untuk ruang usaha common use dengan usaha barunya yaitu jasa pemberangkatan umroh. Ruang usaha mitra 2 dengan penataan layout barang dagangan yang baik maka masih memiliki satu ruang yang tidak digunakan namu akan direncanakan oleh mitra atas usul dari pengabdi untuk usaha lain yaitu antara penjualan pulsa atau jasa pencucian sepatu dan helm yang belum banyak di daerah mitra 1 .

3. UMKM mitra 1 dan mitra 2 memberikan kontribusi dan kerjasama yang baik yaitu dengan bersedia mengeluarkan dana pendamping untuk pembuatan ruang usaha yang melebihi dana yang dianggarkan.

4. Pendokumentasian kegiatan dilaksanakan untuk mendukung pelaporan pelaksanaan dari program kegiatan pengabdian.

5. Monitoring dan evaluasi kegiatan pengabdian dilakukan kepada kedua UMKM mitra agar sesuai dengan output yang diinginkan.

6. Target luaran untuk bisa menghasilkan artikel ilmiah sudah disubmit ke jurnal yang dituju.
Profil UMKM SB Alat Kebersihan

Rosita, Nugroho, L., Ilmi, MB., (2014), Analisis Sistem Informasi Akuantansi Pada Kinerja UMKM dengan Laporan Keuangan Sebagai Variabel Intervening, Jurnal Graduasi, 32, Maret 2014.

Rosita, Rachmawati, I A K, \& Nugroho, KL., (2015), Analisis system informasi akuntansi pada koperasi yang sesuai dengan SAK ETAP. Jurnal Akuntansi Dan Sistem Teknologi Informasi, 11, (2)

Rosita, Mutmainah, H., \& Ida Ayu Kade Rachmawati, I A K., (2015), Analisis Penerapan Sistem Informasi Akuntansi Dan Sistem Informasi Pemasaran Pada Industri Mebel Di Desa Mojosong, Jurnal Bhirawa, 2, (2).

\section{DAFTAR PUSTAKA}

Profil UMKM Nufarozan Bedding Goods 